\title{
An unexplained oxidative haemolysis with pigment nephropathy
}

\author{
Naveen Arunachalam Subramanian, ${ }^{\circledR}$ Vengadakrishnan Krishnamoorthy, \\ Vasanthan Krishnan, Sudha Madhavan
}

General Medicine, Sri Ramachandra Medical College and Research Institute, Chennai, India

\section{Correspondence to} Professor Vengadakrishnan Krishnamoorthy, drkvk1975@gmail.com

Accepted 8 July 2019

\section{Check for updates}

(C) BMJ Publishing Group Limited 2019. No commercial re-use. See rights and permissions. Published by BMJ.

\begin{tabular}{|l|}
\hline To cite: \\
Arunachalam Subramanian N, \\
Krishnamoorthy V, \\
Krishnan V, et al. BMJ Case \\
Rep 2019;12:e230994. \\
doi:10.1136/bcr-2019- \\
230994 \\
\hline
\end{tabular}

\section{DESCRIPTION}

A 46-year-old man presented with breathlessness, icterus, passage of dark-coloured stools and urine for 1 day. His medical history included recent treatment for varicella infection with oral acyclovir and using Siddha medicines for constipation occasionally. On evaluation, he had bilateral crepitations, low saturation $\left(\mathrm{SpO}_{2}-66 \%\right)$ without cyanosis or anaemia, mild indirect hyperbilirubinaemia, elevated methaemoglobin levels (33.6\%) with type 1 respiratory failure on arterial blood gas analysis and normal urine analysis.

Initial chest X-ray showed bilateral lower zone non homogeneous opacities (figure 1A). He was treated as post varicella pneumonia in Intensive Care Unit (ICU) with non-invasive ventilation, antibiotics and other supportive measures. CT thorax showed consolidation in bilateral lower lobes (figure 1B).

Since low saturation persisted despite improvement in hypoxia, the patient was given methylene blue $80 \mathrm{mg}(1 \mathrm{mg} / \mathrm{kg})$ and ascorbic acid considering significant methaemoglobinaemia. He developed haematuria a day later. Further evaluation revealed haemolytic anaemia, marked indirect hyperbilirubinaemia, rhabdomyolysis and myoglobinuria.

Peripheral smear showed spherocytes with bite cells and blister cells, neutrophilia with toxic changes and adequate platelets (figure 1C). Supra vital stain revealed Heinz bodies (figure 1D). Direct and indirect Coomb's tests were negative. In view of acute severe oxidative haemolysis, glucose 6

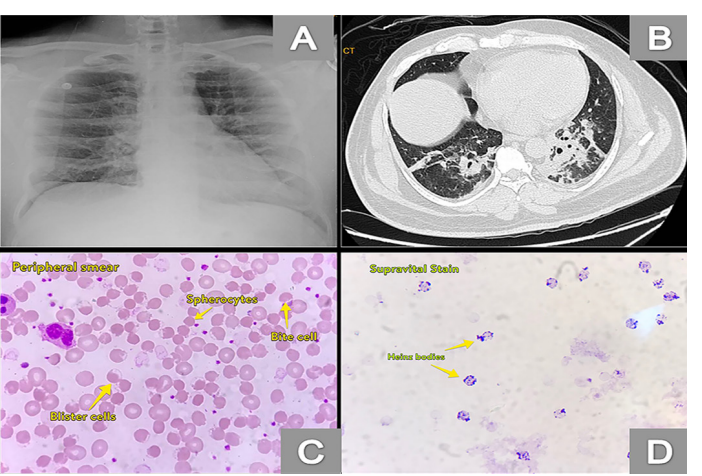

Figure 1 (A) Chest X-ray showing bilateral lower zone non-homogeneous opacities. (B) Axial section of CT chest showing consolidation in bilateral lower lobes. (C) Peripheral smear showing spherocytes with bite cells and blister cells. (D) Supra vital stain showing Heinz bodies.

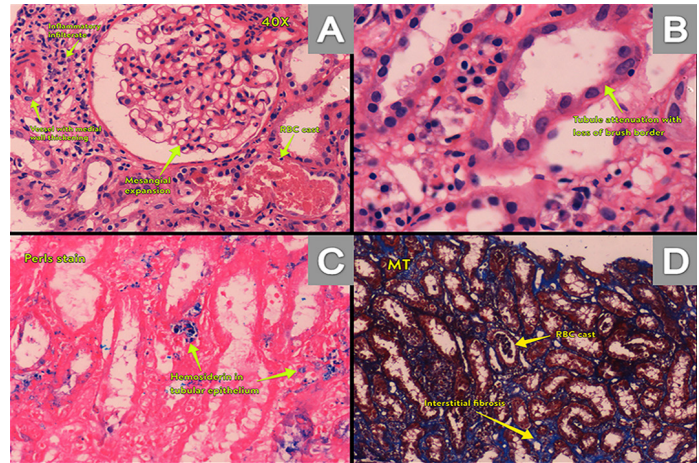

Figure 2 (A) Glomeruli showing mesangial matrix expansion, tubules with RBC casts, interstitial inflammation and blood vessels with medial wall thickening. (B) Dilatation of tubules with attenuation of lining epithelium and loss of brush border. (C) Perl's prussian blue stain showing haemosiderin in the tubular epithelial cells. (D) Masson's trichrome stain confirming the presence of RBC casts and interstitial fibrosis.

phosphate dehydrogenase (G6PD) assay done was normal and considered false negative.

He developed acute kidney injury secondary to haemolysis and rhabdomyolysis. The need for exchange transfusion was deferred since he improved with packed red blood cells transfusion and serial haemodialysis.

After stabilisation, renal biopsy done showed features of acute tubular injury with pigment nephropathy. ${ }^{1}$ Glomeruli showed mesangial matrix expansion, tubules with red blood cell (RBC) casts, interstitial inflammation and blood vessels with medial wall thickening and luminal narrowing (figure 2A). Dilatation of tubules with attenuation of lining epithelium and loss of brush border (figure 2B). Perl's prussian blue stain showed haemosiderin in the tubular epithelial cells (figure 2C). Masson's trichrome stain confirmed the presence of RBC casts and interstitial fibrosis (figure 2D).

Four weeks after discharge with a diagnosis of haemoglobin cast nephropathy following oxidative haemolysis, his renal function resolved completely.

In adults, acute on chronic haemolysis following infection may be seen in hereditary spherocytosis, elliptocytosis, enzymopathies, paroxysmal nocturnal haemoglobinuria $(\mathrm{PNH})$, cold agglutinin disease $(\mathrm{CAD})$, drugs, toxins and autoimmune conditions. ${ }^{2} \mathrm{PNH}$ is commonly characterised by venous thrombosis, neutropaenia and thrombocytopaenia. ${ }^{3}$ The common enzymopathies other than G6PD and their common associations include 
pyruvate kinase (neonatal jaundice, splenomegaly, echinocytes on peripheral smear), pyrimidine 5 nucleotidase (basophilic stippling of RBC) and glucose 6 phosphate isomerase (neuromuscular manifestations). ${ }^{4} \mathrm{CAD}$ is characterised commonly by episodic, cold induced predominantly extravascular haemolysis and rarely acrocyanosis/othervaso-occlusive phenomena. Among the handful case reports of varicella infection with CAD published, majority presented in young age with positive Coomb's test, erythrophagocytosis and responded well to steroids. ${ }^{56}$ Absence of the above findings, presence of typical peripheral smear picture and frequent association of oxidative haemolysis with G6PD deficiency makes it the most probable aetiology.

Baehner et $\mathrm{al}^{7}$ has explained the initial presentation with mild haemolysis during infections that even the hydrogen peroxide generated by the phagocytosing polymorphonuclear leucocytes may induce oxidant stress haemolysis in G6PD-deficient individuals. $^{7}$ Several drug triggers have been reported as a cause of methaemoglobinaemia and haemolysis, none of which

\section{Patient's perspective}

When I came to the hospital I did not think I would have such a complication and I would be undergoing haemodialysis. The hospital stay was expensive and longer than I expected. Somehow my family managed to afford the expenditure and they gave me immense moral support. Now I believe my constant prayers and the effort of my team of doctors helped me recover soon.

\section{Learning points}

Do not be in a hurry to treat methaemoglobinaemia with methylene blue.

- Glucose 6 phosphate dehydrogenase (G6PD) assays may be false negative during acute haemolysis.

- Infections may precipitate haemolysis in G6PD-deficient individuals. were evident in this case. ${ }^{8}$ Methylene blue is contraindicated in G6PD-deficient individuals because of oxidative properties and insufficient nicotinamide adenine dinucleotide phosphate (NADPH) production for methylene blue reduction. ${ }^{9}$ It must have triggered the catastrophic haemolysis and pigment nephropathy in this patient.

To confirm our G6PD deficiency hypothesis repeat assay is planned later.

Acknowledgements Sincere thanks to the Pathologists Dr Rajendran, Dr Subalakshmi B, Dr Barathi G, Dr Anusha Ganapathi, Haematologist Dr Krishnarathinam and Nephrologists Dr Jayakumar M, Dr Ramalakshmi for their valuable inputs which helped in the management of this patient.

Contributors All authors collected the case details. NAS prepared the manuscript, with inputs from VeK, VaK and SM. All authors approved the manuscript, and all authors agree to be accountable for all aspects of the work in ensuring that questions related to the accuracy or integrity of any part of the work are appropriately investigated and resolved.

Funding The authors have not declared a specific grant for this research from any funding agency in the public, commercial or not-for-profit sectors.

Competing interests None declared.

Patient consent for publication Obtained.

Provenance and peer review Not commissioned; externally peer reviewed.

\section{REFERENCES}

1 O'Donnell WM. Renal siderosis in hemoglobinuric nephropathy. Am J Pathol 1950;26:899

2 Tabbara IA. Hemolytic anemias. Diagnosis and management. Med Clin North Am 1992;76:649-68.

3 Hillmen $\mathrm{P}$, Lewis SM, Bessler M, et al. Natural history of paroxysmal nocturnal hemoglobinuria. N Engl J Med 1995;333:1253-8.

4 Luzzatto L. Hemolytic anemias and anemia due to acute blood loss. Harrison's Principles of Internal Medicine 2012:872-97.

5 Swiecicki PL, Hegerova LT, Gertz MA. Cold agglutinin disease. Blood 2013; 122:1114-21.

6 Friedman HD, Dracker RA. Cold agglutinin disease after chicken pox. An uncommon complication of a common disease. Am J Clin Pathol 1992;97:92-6.

7 Baehner RL, Nathan DG, Castle WB. Oxidant injury of caucasian glucose-6-phosphate dehydrogenase-deficient red blood cells by phagocytosing leukocytes during infection. $J$ Clin Invest 1971;50:2466-73.

8 Curry SC, Kang AM. Hematologic syndromes: hemolysis, methemoglobinemia, and sulfhemoglobinemia. Critical care toxicology 2016:1-8.

9 Rosen PJ, Johnson C, McGehee WG, et al. Failure of methylene blue treatment in toxic methemoglobinemia. association with glucose-6-phosphate dehydrogenase deficiency. Ann Intern Med 1971;75:83-6.

Copyright 2019 BMJ Publishing Group. All rights reserved. For permission to reuse any of this content visit

https://www.bmj.com/company/products-services/rights-and-licensing/permissions/

BMJ Case Report Fellows may re-use this article for personal use and teaching without any further permission.

Become a Fellow of BMJ Case Reports today and you can:

- Submit as many cases as you like

- Enjoy fast sympathetic peer review and rapid publication of accepted articles

- Access all the published articles

- Re-use any of the published material for personal use and teaching without further permission

Customer Service

If you have any further queries about your subscription, please contact our customer services team on +44 (0) 2071111105 or via email at support@bmj.com.

Visit casereports.bmj.com for more articles like this and to become a Fellow 